\title{
Machiavellianism: Dimensionality of the Mach IV and its Relation to Self-Monitoring in a Spanish Sample
}

\author{
Susana Corral and Esther Calvete \\ University of Deusto
}

\begin{abstract}
The aim of this study was to assess the measurement model of a Spanish version of the Mach IV Scale (Christie, 1970b), used to measure Machiavellianism, and its relation with the Self-Monitoring Scale (Snyder \& Gangestad, 1986). 346 undergraduate students (70 males and 276 females) filled in both scales. The results of confirmatory factor analyses showed a four-factor structure to be the most adequate model for the Mach IV, with the following factors: Positive Interpersonal Tactics, Negative Tactics, Positive View of Hunan Nature, and Cynical View of Human Nature. These results are not in accordance with the original factor structure but are consistent with other authors' findings. A structural model between Machiavellianism and self-monitoring was tested, showing statistically significant paths between interpersonal tactics and one self-monitoring subscale.
\end{abstract}

Key words: Machiavellianism, self-monitoring, confirmatory factor analysis

El objetivo de este estudio fue evaluar el modelo de medida de una versión española de la escala Mach IV (Christie, 1970b), utilizada para medir el maquiavelismo, y su relación con la escala de Auto-observación (Snyder \& Gangestad, 1986). 346 estudiantes universitarios (70 hombres y 276 mujeres) completaron ambas escalas. Los resultados de los análisis factoriales confirmatorios realizados mostraron que, para el Mach IV, el modelo más adecuado era una estructura de cuatro factores: Tácticas Interpersonales Positivas, Tácticas Interpersonales Negativas, Visión Positiva de la Naturaleza Humana y Visión Cínica de la Naturaleza Humana. Estos resultados difieren de la estructura factorial original, pero son congruentes con las aportaciones de otros autores. Se sometió a prueba un modelo estructural entre maquiavelismo y auto-observación, encontrando relaciones estadisticamente significativas entre tácticas interpersonales y una subescala de auto-observación.

Palabras clave: maquiavelismo, auto-observación, análisis factorial confirmatorio

The authors thank Olga Cardeñoso and Mirko Gerolin for their assistance on the translation of the questionnaires.

Correspondence concerning this article, as well as requests for the Spanish versions of both questionnaires, should be addressed to Esther Calvete, Department of Psychology. University of Deusto. Apdo. 1. 48080 Bilbao (Spain). E-mail; ecalvete@ fice.deusto.es 
The personality construct of Machiavellianism is based on the biography of Machiavelli, a 16th century Italian politician. Machiavelli described the political flirtations of his time, but after his death, the Catholic Church prohibited his two main works, The Discourses and The Prince. This latter work stereotyped the Machiavellian person as perverse, cynic, astute, hypocritical, and always willing to deceive others. Nowadays, a Machiavellian person is considered to be endowed with practical intelligence, emotional control, and very high achjevement motivation, dropping the negative connotation (Pastor, 1982).

Christie (1970a) was the pioneer author to focus on this topic, recapturing the conception of the original author's hostile syndrome. Christic postulated that the tendency to accept Machiavelli's beliefs about the world and human nature was a measurable individual differential variable and proposed a three-dimension structure for this construct. The first dimension refers to the use of manipulative tactics in interpersonal relationships. The second dimension consists of a cynical view of human nature as weak, cowardly, and susceptible to social pressures. And the third dimension is described as distegard for conventional morality.

The development of instruments to measure Machiavellianism by the original author went through several phases (Christie, 1970b), ending in two different versions of the Mach scale. The Mach IV is made up of 20 items, from an original pool of 71 . These items were selected by counterbalancing the wording of the items, content variety, and discriminatory power. From these 20 items, 10 refer to Machiavellianism and the other 10 to non-Machiavellianism. In order to avoid social desirability in the responses to the Mach IV, the Mach $\mathrm{V}$ was designed with a forced-choice format, instead of the original Likert-type format. The dimensionality of the Mach IV scale has been examined in several studies and various factor structures have been found. These results have left the entire construct of Machiavellianism open to several critiques.

When Christic (1970b) developed the Mach IV, he classified the items into the above-mentioned three categories: Interpersonal Tactics, Cynical View of Human Nature, and Disregard for Conventional Morality. The last category has the fewest items because "Machiavelli was less concerned with abstractions and ethical judgements than with pragmatic advice" (Christie, 1970b, p. 14). Actually, the Mach IV scale has only two items in this category and one of them (item 19) has been dropped in studies because of poor psychometric properties. In consequence, several studies show Disregard for Conventional Morality as the least reliable subscale of the Mach IV, with the most complex factor loadings. The other two factors, Tactics and Views, are generally supported by various studies, although this is masked by the tendency of positively and negatively worded items to load on separate factors (Ahmed \& Steward, 1981; Hunter, Gerbing, \& Boster, 1982). Fehr, Samsom, and Paulhus (1992), after carrying out a comprehensive review of the literature, recommended using the Mach IV scale and scoring the subfactots (Tactics and
Cynicism) separately. Corzine (1997) revised several studies on the dimensionality of the Mach IV and concluded that the different factor structures found in the literature indicate that further investigation of measurement issues in Machiavellianism is warranted.

Machiavellianism has been studied in connection with the profession a supposedly Machiavellian person would choose. It has been suggested, in a stereotyped way, that high-scoring Machiavellians would prefer a business occupation, whereas helping professions would be less preferred (Skinner, Giokas, \& Horstein, 1986). Some studies have reported that law students had the highest Mach scores of all students (Werthein, Widom, \& Wortzel, 1978). However, other studies have found no support for this hypothesis (Hunt \& Chonko, 1984).

Machiavellianism has been associated with other psychological constructs, such as paranoia (Christoffersen \& Stamp, 1995), narcissism (McHoskey, 1995), psychopathy (McHoskey, Worzel \& Szyarto, 1998), locus of control (Gablc \& Dangello, 1994), or depression (Bakir, Yilmas \& Yavas, 1996). It has also been associated with more basic dimensions of personality, such as psychoticism, extraversion, and neuroticism, from Eysenck's three-dimensional personality theory (Allsopp, Eysenck, \& Eysenck, 1991). These authors found that Machiavellianism correlates positively with psychoticism and extraversion. There are also a number of researchers who have investigated the relation between Machiavellianism and self-monitoring. This paper deals with these two constructs as part of a more complex research concerning the physiological detection of deception. Both personality traits (Machiavellianism and self-monitoring) have been said to be acting as moderating variables in the psychophysiological detection of deception (Bradley \& Rettinger, 1992).

Self-monitoring has been conceptualized as the way people monitor and control their public appearance in social and interpersonal relationships (Snyder, 1987). The selfmonitoring individual is particularly sensitive about expression and self-presentation of other people in social situations and uses these cues as guidelines for monitoring his or her own self-presentation.

In 1974, Snyder developed a scale to measure selfmonitoring, proposing a general factor underlying the scale (Briggs, Cheek, \& Buss, 1980; Lennox \& Wolfe, 1984; Snyder, 1987). Snyder and Gangestad (1986) proposed a reduced version of the Self-Monitoring Scale with 18 items in order to increase the reliability of the scale while maintaining its construct validity.

The factor analyses performed on the Self-Monitoring Scale bave usually yielded a three-factor model. These three factors have been labeled as Acting, Other-Directedness, and Extraversion, according to Briggs, Cheek, and Buss (1980), and as Expressive-Sell Control, Social Presence Stage, and Other-Directed Sel[-Presentation, according to Snyder and Gangestad (1986). 
Lennox and Wolfe (1984) developed their own SelfMonitoring Scale (Revised Self-Monitoring Scale; RSMS), with 13 Likert-format items, reporting a two-factor structure: Ability to Modify Self-Presentation and Sensitivity to the Expressive Behavior of Others.

Briggs and Cheek (1988) attempted to confirm Snyder's theory, for which purpose they carried out a factor analysis of the reduced version of the Self-Monitoring Scale, reporting a bidimensional structure; the first factor was a combination of the Extraversion and Acting factors, and the second, the Other-Directedness factor. But these results have not found support in other research, where two factors clearly emerged: the Extraversion factor and a second factor that was a combination of Other-Directedness and Acting (Montag \& Levin, 1990). Several researchers have performed factor analysis on the Self-Monitoring Scale using Spanish samples, stating that the dimensionality of this construct is still open to discussion. Avia, Carrillo, and Rojo (1987), using the Self-Monitoring Scale, along with the three dimensions described by Briggs, Cheek, and Buss (1980), found a fourth factor, which they called Consistency Principles-Behavior.

Romero, Luengo, Garra, and Otero-López (1994) carried out an exploratory factor analysis of the 18 items comprising the Reduced Self-Monitoring Scale (Snyder \& Gangestad, 1986) and the 13 items from the Revised Self-Monitoring Scale (Lennox \& Wolfe, 1984). They reported that, except for three items, all the items from the Reduced SelfMonitoring Scalc grouped into two factors. The first one was composed of items from the Other-Directedness and the Acting factors, and the second one was identified as Extraversion. These results led the authors to conclude that the factor structure of the abbreviated scale by Snyder and Gangestad (1986) appears to be bidimensional.

From a theoretical point of view, a positive relationship can be hypothesized between Machiavellianism and selfmonitoring, because both of them involve the use of impression management (Fehr, Samsom, \& Pauhlus, 1992). However, there are inconsistencies in the results obtained by various studies. Ickes, Reidhead, and Patterson (1986) reported a low positive correlation between both variables, whereas Snyder (1974) found Machiavellianism and selfmonitoring to be unrelated. In this paper, we suggest that these results might be due to the fact that Machiavellianism and self-monitoring are multidimensional constructs that include different components that are not necessarily related.

The aims of this study were: first, to assess the structure of the Mach IV Scale, fitting various measurement models, especially those that integrate the distinction tactics-views, with the aspect of positively and negatively worded items. Second, to study differences between psychology and law students in Machiavellianism, expecting to find higher scores in the latter ones. And third, to explore the relationship between Machiavellianism and self-monitoring, in order to identify which dimensions (if any) of these constructs are related.

\section{Method}

\section{Participants}

Participants were 346 voluntary students, 156 psychology students and 190 law students, with ages between 18 and $36(M=19.55, S D=1.37)$. There were 276 women $(79.8 \%)$ and 70 men $(20.2 \%)$.

In the subgroup of psychology students, there were 138 women $(88.5 \%)$ and 18 men $(11.5 \%)$, with an average age of $19.60(S D=1.35)$. In the subgroup of law students, there were 138 women $(72.6 \%)$ and 52 men $(27.4 \%)$ with an average age of $19.50(S D=1.40)$. The predominance of female participants in the two samples of this study, while representative of the university populations in which it was carried out, represents a bias that will be extensively commented upon.

\section{Instruments}

Mach IV (Christie, 1970b). The Mach IV is made up of 20 items, 10 indicating high Machiavellianism and 10 indicating the opposite (low Machiavellianism). The items reflect ways of thinking and opinions about people and things. Participants were requested to rate the extent to which they agreed or disagreed with the statements on a 6-point Likert-type scale: $1=$ Strongly Disagree, $2=$ Disagree, 3 $=$ Slightly Disagree, $4=$ Slightly Agree, $5=$ Agree and $6=$ Strongly Agree. Alpha coefficients of .70 to .76 have been reported for the Mach IV Scale by many researchers (Gable \& Topol, 1987; Hunt \& Chonko, 1984; Zook \& Sipps, 1986).

Reduced Self-Monitoring Scale (Snyder \& Gangostad, 1986). This scale is made up of 18 items, which reflect ways of behaving in interpersonal interactions. Participants were asked to rate the extent to which the statement reflected their own behavior on a 5-point Likert-type scale: $1=$ Totally Disagree, 2 = Slightly Disagree, $3=$ Unable to make one's mind, $4=$ Slightly Agree, and $5=$ Totally Agree. The original Self-Monitoring Scale rating score was True-False (Snyder, 1974) but it was changed into a Likert-type scale for psychometric purposes. The alpha coefficient reported by Snyder and Gangestad (1986) for the Reduced SelfMonitoring Scale was 70.

The adaptation of the Mach-IV and the Reduced SelfMonitoring Scale was done using the back-translation method. First, a bilingual psychologist transiated the English questionnaires into Spanish. Then, another bilingual psychologist translated the Spanish versions back into English. The original source and the back-translated items were compared for non-equivalence of meaning, and discrepancies were corrected. The process continued until no semantic differences were noticed between both questionnaire forms. 


\section{Procedure}

Participants filled in the Spanish versions of the Mach IV and the Reduced Self-Monitoring Scale. In order to protect participant's anonymity and get more honest answers, they were not required to give their names, although they were asked to do so if they wanted to know their scores. All the students were volunteers from the sccond year of Psychology and Law faculties. The data gathering took place in the students' classroom, collectively, in one session that lasted approximately 45 minutes.

\section{Statistical Analyses}

The correlation matrixes of the items from the Mach IV (20 items) and the Self-Monitoring Scale (18 items) were computed using the PRELIS2 program (Jöreskog \& Sörbom, 1996a).

The different models fitted in this study were conducted via maximum likelihood estimation with LISREL8 (Jöreskog \& Sörbom, 1996b). Goodness of fit was assessed by the Goodness-of-Fit Index (GFI), the Adjusted-Goodness-of-Fit Index (AGFI), the Root Mean Squared Error of Approximation (RMSEA), and the Comparative Fit Index (CFI). Browne and Cudeck (1993) suggested that an RMSEA of about 0.05 reflects a close fit of the model in relation to its degrees of freedom, whereas values as high as 0.08 reflect a reasonable etror of approximation. Generally, GFI, AGFI, and CFI values between 0.80 and 0.90 represent adequate to good fit, and values greater than or equal to 0.90 reflect good fit. Due to the small percentage of male participants, all the measurement models were reestimated for the female sample.

\section{Results}

\section{Measurement Model of the MACH-IV}

Four different models were tested in a series of confirmatory factor analyses:

Modcl 1: Machiavellianism as a one-factor structure.

Model 2: Machiavellianism as a two-factor structure: Interpersonal Tactics and Cynical View of Human Nature.

Model 3: Machiavellianism as a three-factor structure: Interpersonal Tactics, Cynical View of Human Nature, and Disregard for Conventional Morality: This model represents the original factor structure proposed by Christie (1970b).

Model 4: Machiavellianism as a four-factor structure: Positive Interpersonal Tactics, Negative Interpersonal Tactics, Positive View of Human Nature, and Cynical View of Human Nature.

In all the models, the factor loading matrix was full and fixed (LX). Each item hach a nonzero loading on the latent variable that it was designed to measure, and zero loading on the other factors. The factor correlation matrix ( $\mathrm{PH}$ ) was symmetrical, with all coefficients freely estimated, thereby indicating that the factors were correlated. The error variancecovariance matrix (TD) was symmetrical, with diagonal elements free and off-diagonal elements fixed at zero.

The comparison of the models (See Table 1) supported the proposed four-factor model. In the total sample, Model 4 reduced the value of chi-squared significantly with respect to Model 2, $\nabla \chi^{2}(5)=97, p<.0001$, and to Model 3, $\nabla \chi^{2}(3)=88, p<.0001$. The same effect was observed in the female sample. In Table 2, the main parameters of the measurement model for the four-factor structure are shown. The measurement model specifies the pattern by which each

Table 1

Goodness-of-Fit Indexes for the Mach IV Measurement Models (Total and Female Samples)

\begin{tabular}{|c|c|c|c|c|c|c|c|}
\hline Model & Sample & $x^{2}$ & df & RMSEA & GFI & AGFI & $\mathrm{CFI}$ \\
\hline Model 1. One factor: & Total & $417^{*}$ & 170 & 0.065 & 0,87 & 0.84 & 0.65 \\
\hline Machiavellianism & Female & $338 *$ & 170 & 0.060 & 0.87 & 0.84 & 0.67 \\
\hline Model 2. Two factors: & Total & $364 *$ & 169 & 0.058 & 0.89 & 0.86 & 0.72 \\
\hline $\begin{array}{l}\text { Interpersonal Tactics and } \\
\text { Cynical View of Hurnan Nature }\end{array}$ & Female & $282^{*}$ & 169 & 0.049 & 0.90 & 0.87 & 0.78 \\
\hline Model 3. Three factors: & Total & $355^{*}$ & 167 & 0.057 & 0.89 & 0.86 & 0.73 \\
\hline $\begin{array}{l}\text { Interpersonal Tactics, Cynical View } \\
\text { of Human Nature, and Morality }\end{array}$ & Female & $284^{*}$ & 167 & 0.051 & 0.90 & 0.87 & 0.77 \\
\hline Model 4. Four factors: & Total & $267 *$ & 164 & 0.043 & 0.93 & 0.91 & 0.85 \\
\hline $\begin{array}{l}\text { Positive Interpersonal Tactics, } \\
\text { Negative Interpersonal Tactics, } \\
\text { Positive View of Human Nature, } \\
\text { and Cynical View of Human Nature }\end{array}$ & Female & $204^{*}$ & 164 & 0.030 & 0.93 & 0.91 & 0.92 \\
\hline
\end{tabular}

$* p<.01$. 
Table 2

The Four-Factor Mach IV Measurement Model (Total and Female Samples)

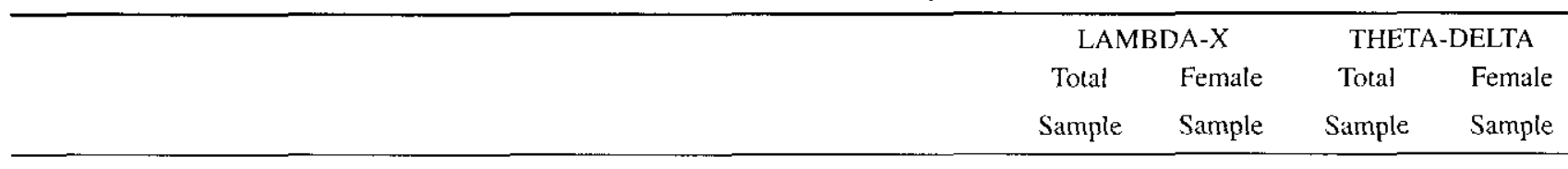

Negative Interpersonal Tactics

1. Never tell anyone the real reason you did something unless it is useful to do so.

\begin{tabular}{|c|c|c|}
\hline 62 & .50 & .80 \\
\hline .55 & .42 & .85 \\
\hline 50 & .39 & .84 \\
\hline .40 & .52 & .83 \\
\hline
\end{tabular}

15. It is wise to flatter important people.

2. The best way to handle people is to tell them what they want to hear.

.52

.79

.79

.70

9. All in all, it is better to be humble and honest than important and dishonest.

10. When you ask someone to do something for you, it is best to give the real reasons for wanting it rather than giving reasons which might carry more weight.

3. One should take action only when sure it is morally right.

16. It is possible to be good in all respects.

Cynical View of Human Nature

5. It is safest to assume that all people have a vicious streak and it will come out when they are given a chance.

17. Barnum was very wrong when he said there's a sucker born every minute.

$\begin{array}{llll}.74 & .68 & .67 & .72 \\ .73 & .67 & .74 & .74 \\ .63 & .58 & .74 & .76 \\ .53 & .48 & .88 & .89 \\ .44 & .43 & .90 & .90 \\ .42 & .49 & .91 & .88\end{array}$

\section{Positive View of Human Nature}

4. Most people are basically good and kind.

11. Most people who get ahead in the world lead clean, moral lives.

.80

.63

.49

14. Most men are brave.

19. People sutfering from incurable diseases should have the choice of being put painlessly to death.

$\begin{array}{lll}.76 & .64 & .65 \\ .75 & .70 & .72 \\ .72 & .63 & .61 \\ .60 & .75 & .74 \\ .59 & .83 & .81 \\ .51 & .89 & .88\end{array}$

65

72

l

74

81

88

13. The biggest difference between most criminals and other people is that criminals

.

88

item loads on a particular factor. The regression coefficients labeled Lambda-X represent the magnitude of expected change in the itcms for every change in the related latent factor. The Theta-Delta coefficients represent the random measurement error (Byrne, 1998). All the Lambda-X coefficients were statistically different from zero ( $t$-value $>$ \pm 1.96 ) both in the total sample and in the female sample.
The alpha coefficient for the Mach IV scale was .70, with the following values for the subscales: $.50, .53, .62$, and .40 for Positive View of Human Nature, Cynical View of Human Nature, Positive Interpersonal Tactics, and Negative Interpersonal Tactics, respectively. In Table 3 are displayed the means and standard deviations of the Mach IV in the student groups. 
Table 3

Means and Standard Deviations of the Machiavellianism Subscales (1, 2, 3, \& 4) in Psychology Students and Law Students

\begin{tabular}{ccccccccc}
\hline Student Groups & \multicolumn{9}{c}{$M$} & \multicolumn{3}{c}{$S D$} & \\
\cline { 2 - 9 } & 1 & 2 & 3 & 4 & 1 & 2 & 3 & 4 \\
\hline Psychology Students & 13.73 & 16.21 & 25.40 & 11.24 & 2.75 & 4.20 & 5.01 & 2.86 \\
Women & 13.72 & 16.11 & 25.50 & 11.21 & 2.72 & 4.24 & 5.04 & 2.93 \\
Men & 14.00 & 16.83 & 24.50 & 11.44 & 3.06 & 4.02 & 4.74 & 2.43 \\
Law Students & 13.05 & 17.28 & 24.90 & 11.79 & 2.83 & 4.83 & 4.72 & 3.44 \\
Women & 13.11 & 17.03 & 25.13 & 11.40 & 2.69 & 4.72 & 4.6 & 3.24 \\
Men & 12.85 & 17.98 & 24.19 & 12.82 & 3.16 & 5.07 & 5.01 & 3.73 \\
Psychology \& Law Students & 13.36 & 16.80 & 25.13 & 11.54 & 2.81 & 4.58 & 4.85 & 3.20 \\
\hline
\end{tabular}

Note. 1 = Positive View of Human Nature; 2 = Cynical View of Human Nature; 3 = Positive Interpersonal Tactics; $4=$ Negative Interpersonal Tactics.

\section{Factorial Invariance across Psychology and Law Student Samples}

The next step was to evaluate the factor invariance of the Mach IV across two populations (psychology and law students), using multiple-group-covariance-structure analysis. Due to the fact that the proportion of male students was higher in the law sample than in the psychology sample, and that this difference between groups could be acting as a confounding variable, male participants of the samples were dropped in order to carry out these analyses.

Before testing for the invariance of particular parameters across groups, the four-factor model was checked in each group (Model 5 and Model 6), showing adequate fit (see Table 4). Later, three hypotheses were considered:

1. The number of underlying factors was equivalent (Model 7)

2. The pattern of factor loading was equivalent (Model 8)

3. The factor variances and covariances were invariant (Model 9)

Model 7 was obtained by fitting both populations simultancously without constraints. The $\chi^{2}$ and the degrees of freedom for Model 7 are equal to the sum of the $x^{2}$ and degrees of freedom of the four-factor model, fitted to each population separately. The goodness of fit for Model 7 , in which no equality constraints were imposed. yielded a

Table 4

Goodness-of-Fit Indexes for the Hypothesis of Factorial Invariance (Psychology and Law Female Student Groups) $N=276$

\begin{tabular}{lcccccc}
\hline Model & Sample & $x^{2}$ & df & RMSEA & GFI & CFI \\
\hline $\begin{array}{l}\text { Model 5. } \\
\text { (Psychology Students, } n=137 \text { ) }\end{array}$ & Four-Factor Structure & $208^{*}$ & 164 & 0.044 & 0.87 & 0.83 \\
$\begin{array}{l}\text { Model 6. } \\
\text { (Law Students, } n=139)\end{array}$ & Four-Factor Structure & $227^{*}$ & 164 & 0.053 & 0.86 & 0.79 \\
$\begin{array}{l}\text { Model 7. } \\
\text { (Two samples jointly) }\end{array}$ & Unconstrained & $435^{*}$ & 328 & 0.049 & 0.87 & 0.81 \\
$\begin{array}{l}\text { Model 8. } \\
\text { (Two samples jointly) }\end{array}$ & Invariant Factor & $444^{*}$ & 344 & 0.046 & 0.87 & 0.82 \\
$\begin{array}{l}\text { Model 9. } \\
\text { (Two samples jointly) }\end{array}$ & $\begin{array}{l}\text { Invariant Factor } \\
\text { Covariences }\end{array}$ & $453^{*}$ & 354 & 0.045 & 0.87 & 0.82 \\
$\begin{array}{l}\text { Model 10. } \\
\text { (Two samples jointly) }\end{array}$ & $\begin{array}{l}\text { Test for Invariant } \\
\text { Mean Structures }\end{array}$ & $460^{*}$ & 360 & 0.045 & 0.86 & 0.83 \\
\hline
\end{tabular}

$* p<.01$. 
reasonable fit to the data (RMSEA $=0.049, \mathrm{GFI}=0.87$ ), as can be seen in Table 4 .

The second step consisted of testing the hypothesis of invariance of factor loadings. Model 7 was respecified in Model 8, with equality constraints placed on all factor loadings $(L X=I N)$. Results showed that the postulated equality of factor loadings across groups was tenable, $\Delta$ $\chi^{2}(16)=9, p=.8$.

The hypothesis of the invariant factor variance and covariance was tested by imposing equality constraints on $\mathrm{PH}$ matrix $(\mathrm{PH}=\mathrm{IN})$. We compared the fit of Model 9 with that of Model 7 , yielding an $\Delta \chi^{2}$ (26) value of 18 , which was not statistically significant and supported the invariance hypothesis (see Table 4).

\section{Test for Invariant Mean Structures}

Previous research had found that law students had the highest Mach scores (Wertheim, Widom, \& Wortzel, 1978) but other studies did not replicate this result. To clarify these inconsistencies, we conducted a multigroup comparison of latent mean structures, following the procedure described by Byrne (1998).

The model tested (Model 10) could be summarized as follows:

- PH matrix and variances of the errors were freely estimated in each group.

- Factor loadings and all intercepts for the observed measures were constrained equally across groups.

- The four-factor intercepts were freely estimated in the sample of psychology female students and constrained equal to zero in the sample of law female students (reference group).

- Variance associated with the constant remained fixed at 1.00 .

The Kappa values reportcd for the psychology female student group represents latent mean differences between the two groups: Negative Tactics (Kappa $=-0.04, t$-value
$=-0.32)$, Cynical View of Human Nature (Kappa $=-0.28$, $t$-value $=-1.99)$, Positive Tactics $(K a p p a=0.01, t$-value $=$ 0.05 ), and Positive View of Human Nature (Kappa $=0.45$, $t$-value $=2.21)$. These values reveal that only the latent means differences related to the View of Human Nature are statistically significant. Given that the Kappa parameters were estimated just for the psychology female student sample, the values indicate that law students obtain lower scores in Positive View of Human Nature and higher in Cynical View of Human Nature. The estimated model (see Table 4) showed an adequate fit (RMSEA $=0.045, \mathrm{GFl}=$ $0.86, \mathrm{CFI}=0.83$ ).

\section{Measurement Model of the Reduced Self-Monitoring Scale}

Three models for the Self-Monitoring Scale were tested for the total and female samples of students:

Model 11: Self-monitoring as a one-factor structure, according to Snyder (1974).

Model 12: Self-monitoring as a two-factor structure: Other-Directedness and Extraversion.

Model 13: Self-monitoring as a three-factor structure: Acting, Other-Directedness, and Extraversion. ltems were distributed according to the results reported by Briggs, Cheek, and Buss (1980).

In all three measurement models, the parameter TE $(18,17)$ was freely estimated. In Table 5 , the fit indexes are shown; these indexes were remarkably lower in the onedimension model. The two-factor structure, in contrast to the three-dimension structure, reduced the chi-square value significantly in the total and female samples, $\nabla \chi^{2}(2)=18$ and 17 , respectively, $p<.001$. The parameters of this bidimensional structure can be seen in Table 6 . All the Lambda-Y coefficients were statistically different from zero ( $t$-value $> \pm 1.96$ ), although the value of some coefficients was low, especially in the female group. The alpha

Table 5

Goodness-of-Fit Indexes for the Reduced Self-Monitoring Scale Measurement Models (Total and Female Samples)

\begin{tabular}{|c|c|c|c|c|c|c|c|}
\hline Model & Sample & $\chi^{2}$ & $\mathrm{df}$ & RMSEA & GFI & AGFI & CFI \\
\hline Model 11. One factor: & Total & $527^{*}$ & 134 & 0.090 & 0,82 & 0.77 & 0.52 \\
\hline Self Monitoring & Female & $475^{*}$ & 134 & 0.090 & 0.80 & 0.75 & 0.44 \\
\hline Model 12. Two factors: & Total & $310^{*}$ & 133 & 0.060 & 0.91 & 0.88 & 0.78 \\
\hline $\begin{array}{l}\text { Other-Directedness and } \\
\text { Extraversion }\end{array}$ & Female & $281 *$ & 133 & 0.060 & 0.90 & 0.87 & 0.76 \\
\hline Model 13. Three factors: & Total & $328 *$ & 131 & 0.070 & 0.90 & 0.87 & 0.76 \\
\hline $\begin{array}{l}\text { Other-Directedness, Acting, } \\
\text { and Extraversion }\end{array}$ & Female & $298 *$ & 131 & 0.068 & 0.90 & 0.86 & 0.73 \\
\hline
\end{tabular}

$* p<01$. 
coefficient for the Self-Monitoring Scale was .74. The alpha coeflicients for the self-monitoring subscales were .67 and .66 for Other-Directedness and Extraversion, respectively. The means and standard deviations of the self-monitoring subscales in the two student groups were as follows: $M=$ $25.81(S D=5.27)$ for the psychology students and $M=$ $26.60(S D=5.99)$ for the law students in Other-Directedness; and, in Extraversion, $M=27.79(S D=5.58)$ for the psychology students and $M=29.21(S D=5.3$ [) for the law students. For both groups, the values were: $M=26.25$ ( $S D$ $=5.68)$ and $M=28.56(S D=5.47)$ in Other-Directedness and Extraversion, respectively.

\section{Machiavellianism and Self-Monitoring}

Table 7 shows statisticaliy significant correlations between the four subscales of Machiavellianism and the self-monitoring subscales. Based on these data, the rclationship between Machiavellianism and scllmotitoring was studied in the total sample, using structural equation modeling. The four Machiavellianism subscales were hypothesized to be independent latent variables and their influence on the two self-monitoring subscales (Other-Directedness and Extraversion) was estimated in Model 14.

Gamma coefficients were ircely estimated. Two of them were statistically significant $(t$-value $>1.96)$, showing the influence of Negative and Positive Interpersonal Tactics on Other-Directedness. No statistically significant paths were found between the Machiavellianism subscales and extraversion. In Figure 1, the significant parameters are displayed. The goodnessof-fit indexes for Model 14 were adequate, RMSEA = $0.043, \mathrm{GFI}=0.88, \mathrm{AGFI}=0.84$.

Table 6

The Two-Factor Reduced Self-Monitoring Measurement Model (Total and Female Samples)

\begin{tabular}{rrr}
\hline & LAMBDA-Y & THETA-EPSILON \\
Total Female Total Female & Tal \\
\hline
\end{tabular}

Other-Directednes:

10. I'm not always the person. I appear to be.

8. In different situations and with different people, I often act like very different persons.

18. I may deceive people by being friendly when I really dislike them.

5. I guess I put on a show to impress or entertain others.

17. I can look anyone in the eye and tell a lie with a straight face (if for a right end).

11. I would not change my opinions (or the way I do things) in order to please someone for win their favor.

1. I find it hard to imitate the behavior of other people.

3. I can only argue for ideas that I already believe.
.95

.79

.70

.59

.52

.35

.28

.26

$\begin{array}{lll}.94 & .51 & .54 \\ .77 & .64 & .67 \\ .63 & .72 & .77 \\ .58 & .77 & .77 \\ .48 & .86 & .88 \\ .31 & .92 & .94 \\ .28 & .93 & .93 \\ .20 & .97 & .98\end{array}$

\section{Extraversion}

13. [ have never been good at games like charades or improvisational acting.

6. I would probably make a good actor.

12. I have considered being an entertainer.

7. In a group of people, I am rarely the center of attention.

14. I have trouble changing my behavior to suit different people and different situations. .50

4. I can make impromptu speeches even on topics about which I have almost no information. .47

15. At a party, I let others keep the jokes and stories going. 46

16. I feel a bit awkward in company and do not show up quite as well as I should.
9. I am not particularly good at making other people like me.

$\begin{array}{lll}.68 & .69 & .63 \\ .58 & .79 & .81 \\ .46 & .67 & .73 \\ .49 & .75 & .75 \\ .48 & .81 & .82 \\ .47 & .86 & .86 \\ .50 & .80 & .77 \\ .50 & .81 & .75 \\ .32 & .90 & .89 \\ .20 & .93 & .93\end{array}$


Table 7

Intercorrelations of the Machiavellianism $(1,2,3, \& 4)$ and Self-Monitoring (5 \& 6) Subscales $(N=346)$

\begin{tabular}{|c|c|c|c|c|c|c|}
\hline & 1 & 2 & 3 & 4 & 5 & 6 \\
\hline \multicolumn{7}{|l|}{ 1. Positive View of Human Nature } \\
\hline 2. Cynical View of Human Nature & $-.26 * * *$ & & & & & \\
\hline 3. Positive Interpersonal Tactics & $.26 * * *$ & $-.29 * * *$ & & & & \\
\hline 4. Negative Interpersonal Tactics & -.11 & $.52 * 4$ & $-.35 * *$ * 将 & & & \\
\hline 5. Other-Directedness & $-.20 * *$ & $.24 * *$ & $-.47 * * *$ & $.41 * * *$ & & \\
\hline 6. Extraversión & -.02 & .06 & .01 & .12 & $.19 * *$ & \\
\hline
\end{tabular}

$* * p<.001, * * * p<.0001$.

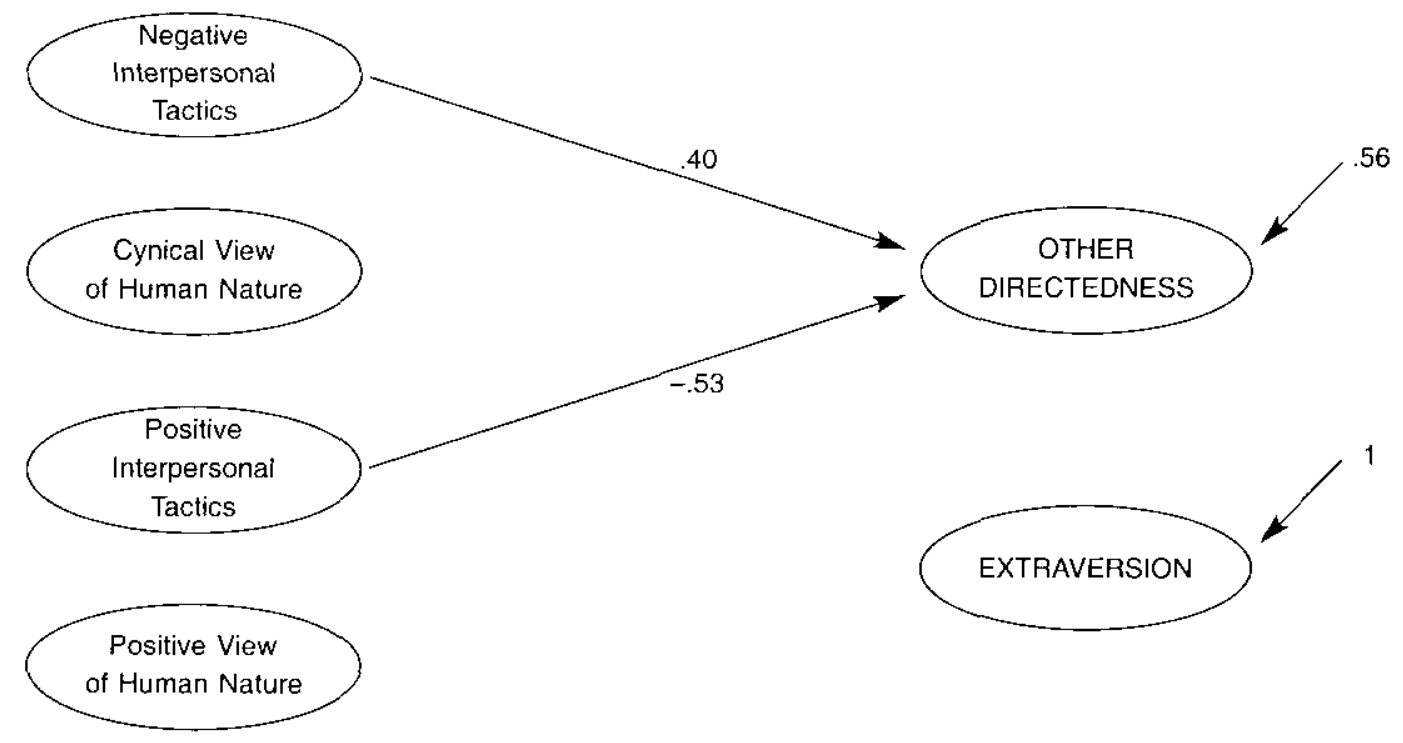

Figure 1, Structural model between Machiavellianism and self-monitoring subscales (standardized Gamma and Zeta coefficients are shown).

\section{Discussion}

The first aim of this study was the evaluation of different measurement models of Mach IV. Previous research had found two of the factors described by Christie (1970b): Interpersonal Tactics and Cynical View of Human Nature. However, results related to the third factor - Morality - were more confusing. On the other hand, several studies have shown the tendency of the Tactics-Views distinction to be confounded with the direction in which the items are keyed (Ahmed \& Steward, 1981; Hunter, Gerbing, \& Boster, 1982).

In this study, the model that fitted the data the best was the one that combined the above-mentioned tendency with the Interpersonal Tactics-View of Human Nature distinction. In consequence, a four-factor structure is proposed for the Mach IV: Negative Interpersonal Tactics, Positive Interpersonal Tactics, Cynical View of Human Nature, and Positive View of Human Nature. The internal-consistency coefficient yielded for the entire Machiavellianism scale is similar to the alpha coefficients reported in several studies (Gable \& Topol, 1987;
Hunt \& Chonko, 1984; Zook \& Sipps, 1986). The small number of male participants in this study requires future research to replicate the Mach IV measurement model and to study the differences of Machiavellianism between sexes.

Some works have previously reported the poor psychometric properties of item 19 , belonging to the Disregard for Conventional Morality factor originally proposed in the Mach IV. This item deals with people's choice of being put to death when suffering from incurable diseases. In our factor analysis, this item appeared in the Positive View of Human Nature and with a positive loading, whereas in the original scale, this item belonged to the Disregard for Conventional Morality factor (Christie, 1970 b). This is probably due to the fact that the social consideration of euthanasia has changed since the original scale was developed in the early $70^{\prime} \mathrm{s}$, and suggests that this item should be eliminated definitely from the scale.

The occupational preferences of Machiavcllian people have been an interesting issue explored in several studies. Wertheim, Widom, and Wortzel (1978) found that law 
students showed the highest scores in Machiavellianism in comparison with other occupations. However, other studies did not find any differences among several professions (Moore, Katz, \& Holder, 1995). In this research, the differences between psychology and law students were assessed as an indicator of the construct validity of Machiavellianism and its measurement. Because of the smaller percentage of males in the student samples of our study and of their disproportionate distribution in both samples, the male students were dropped before carrying out that assessment. After testing the invariance of the factor structure of the Mach IV across these two samples, the latent mean structures were compared. The only statistically significant differences between both groups were obtained for the subscales referring to the perception of human nature. Female law students obtained higher scores in Cynical View and lower in Positive View. There were no differences between female psychology students and female law students in the use of interpersonal tactics. These results, although modest, can be interpreted in the sense that high Machiavellian people prefer studies, such as law, usually associated with professions which are supposed to require specific features related to manipulation of others and a somewhat skeptic vision of human nature. On the other hand, people with an optimistic vision of human values would feel more comfortable choosing professions based on confidence and respect for others. However, the differences found are only related to the female sample. Future studies should confirm whether these differences exist in interaction with sex effect.

Although it was not a main goal of this study, the dimensionality of self-monitoring, using the abbreviated scale by Snyder and Gangestad (1986) was also assessed. The analyses carried out allowed us to confirm that a twodimension structure may be the most appropriate for selfmonitoring, as was already reported in several studies (Rojo \& Carrillo, 1995; Romero, Luengo, Garra, \& Otero-López, 1994). The first dimension is in accordance with the items belonging to Briggs, Cheek, and Buss's (1980) Extraversion factor. People scoring high in this factor could be described as skilled in social situations. The second factor is clearly different, as shown by the low correlation between both factors; it comprises items from the Other-Directedness and Acting factors. This second factor describes a person's trend to manipulate his or her presentation when necessary, even offering a false image of him or herself.

Lastly, the relationship between Machiavellianism and self-monitoring was assessed. The content analysis of the items of both questionnaires showed that the Mach IV items mainly describe a person's beliefs, whereas the items of the Self-Monitoring Scale refer mainly to behavioral consequences. Previous research had suggested that the Mach IV assesses beliefs and attitudes but not behaviors (Kraut \& Price, 1976). Because of this, and from a cognitive approach, in this study, the Mach IV subscales were hypothesized to be independent latent variables, following Wilson, Near, and Miller's (1996) suggestion that there are many aspects of manipulation and cooperation in human life that require a multidimensional scalc. Then, the effect of Machiavellianism on the self-monitoring subscales was considered.

The pattern of structural equations obtained showed two statistically significant coefficients, suggesting that the behavioral style with which a person manipulates the image presented to others is determined by the person's beliefs about the extent to which the use of negative interpersonal tactics is justified. However, the OtherDirectedness factor is not associated with those dimensions of Machiavellianism that refer to a Cynical View of Human Nature. Therefore, the analyses carried out on the different subscales of the Mach IV and the Self-Monitoring Scale show that some of the components of both constructs are associated, whereas others are independent. Thus, the variable Extraversion is not associated with any of the dimensions of Machiavellianism. These data could clarify the lack of consistent results obtained in previous studies (Ickes, Reidhead, \& Patterson, 1986; Snyder, 1974), but they should be interpreted with caution because of the characteristics of the samples used in this study, composed mostly of women. On the other hand, the joint study of these two constructs, Machiavellianism and self-monitoring, is especial meaningful in the context of psychophysiological detection of deception. It would be interesting to evaluate the role played by the dimensions identified in this study in the prediction of various profiles of physiological responsivity when being examined using the Control Question Test (Raskin, 1979) or the Guilty Knowledge Test (Lykken, 1959).

To sum up, we propose a four-factor structure for the Mach IV, developed by Christic (1970b), with the following factors: Positive Tactics, Negative Tactics, Positive Vjew of Human Nature, and Cynical View of Human Nature. Machiavellianism and self-monitoring were also studied, in an attempt to examine the relationship between them, revealing that both constructs are related only in some components: the acceptance of the use of Negative Interpersonal Tactics associated with the dimension of OtherDirectedness. We suggest that the reason for the inconsistency of the results found in the literature may be due to the fact that some components are independent, whereas others are interrelated.

\section{References}

Ahmed, S.M.S., \& Stewart, R.A.C. (1981). Factor analysis of the Machiavellian scales. Social Behaviour and Personality, 9. 113-115.

Allsopp, J., Eysenck, H.J.. \& Eysenck, S.B.G. (1991). Machiavellianism as a component in psychoticism and extraversion. Personality and Individual Differences, 12, 29-41. 
Avia, M.D., Carrillo, J.M., \& Rojo, N. (1987). Personalidad y diferencias sexuales. Proyecto de investigación. Instituto de la Mujer.

Bakir, B., Yilmaz. U.R., \& Yavas, 1. (1996). Relating depressive symptoms to Machiavellianism in a Turkish sample. Psychological Reports, 78, 1011-1014.

Bradley, M. T. \& Rettinger, J. (1992). Awareness of crime-relevant information and the Guilty Knowledge Test. Joumal of Applied Psychology, 77, 55-59.

Briggs, S.R., \& Cheek, J.M. (1988). On the nature of selfmonitoring: Problems with validity. Joumal of Personality and Social Psychology; 54, 663-678.

Briggs, S.R., Cheek, J.M. \& Buss, A.H. (1980). An analysis of the Self-Monitoring Scale. Journal of Personality and Social Psychology, 38, 679-686.

Browne, M.W. \& Cudeck, R. (1993). Alternative ways of assessing model fit. In K.A. Bollen \& J.S. Long (Eds.), Testing structural equation models (pp. 136-162). Newbury Park, CA: Sage.

Byrne, B.M. (1998). Struchural equation modeling with LISREL, PRELIS, and SIMPLIS: Basic concepts, applications, and programming. Mahwah, NJ: Erlbaum.

Christie, R. (1970a). Why Machiavelli? In R. Christie \& F.L. Geis (Eds.), Studies in Machiavellianism (pp. 1-9). New York: Academic Press.

Christie, R. (1970b). Scale construction. In R. Christie \& F.L. Geis (Eds.), Studies in Machiavellianism (pp. 10-34). New York: Academic Press.

Christoffersen, D., \& Stamp, C. (1995). Examining the relationship between Machiavellianism and paranoia. Psychological Reports, $76,67-70$.

Corzine, J. B. (1997) Machiavellianism and management: A review of single-nation studies exclusive of the USA and cross-rational studies. Psychological Reports, 80, 291-304.

Fehr, B., Samsom, D., \& Pauhlus, D.L. (1992). The construet of Machiavellianism: Twenty years later. Advances in Persontality Assessment, 9, 77-116.

Gable, M.. \& Dangello, F. (1994). Locus of control, Machiavellianism, and managerial job performance. Joumal of Psychology, 128 , 599-608.

Gable, M., \& Topol, M.T. (1987). Job satisfaction and Machiavellian orientation among department store exccutives. Psychological Reports, 60, 211-216.

Hunt, S.D., \& Chonko, L.B. (1984). Marketing and Machiavellianism. Journal of Marketing, 48, 30-42.

Hunter, J.E., Gerbing, D.W., \& Boster, F.J. (1982). Machiavellian beliefs and personality: Construct invalidity of the Machiavellian dimension. Journal of Personality and Social Psychology, 43, 1293-1305.

Ickes, W., Reidhead, S., \& Patterson, M. (1986). Machiavellianism and self-monitoring: As different as "me" and "you," Social Cognition, 4, 58-74.

Jöreskog. K.G.. \& Sörbom, D. (1996a). PRELIS2 user's reference guide. Chicago: Scientific Software International.

Jöreskog, K.G., \& Sörbom, D. (1996b), LISREL\& user's reference gutde. Chicago: Scientific Software Internationa].
Kraut, R.E., \& Price, J.D. (1976). Machiavellianism in patients and their children. Journal of Personality and Social Psychology, 33, 782-786.

Lennox, R.D., \& Wolfe, R.N. (1984), Revision of the SelfMonitoring Scale. Journal of Personality and Social Psychology, 46, 1349-1364.

Lykken, D.T. (1959). The GSR in the detection of guilt. Journal of Applied Psychology, 46, 385-388.

McHoskey, J. (1995). Narcissism and Machiavellianism. Psychological Reports, 77, 755-759.

McHoskey, J.W., Worzel, W., \& Szyarto, C. (1998). Machiavellianism and psychopathy. Joumal of Personality and Social Psychology, 74, 192-210.

Montag, I., \& Levin, J. (1990). The location of the Self-Monitoring Scale in the factor space of the EPQ and the 16PF. Joumal of Research in Personality, 24, 45-56.

Moore, S., Katz, B., \& Holder, J. (1995). Machiavellianism and medical career choices. Psychological Reports, 76, 803-807.

Pastor, G. (1982). Síndrome frío de personalidad sagaz. Psicología social del maquiavelismo. Salamanca, Spain: Bibliotheca Salmanticensis.

Raskin, D. C. (1979). Orienting and defensive reflexes in the detection of deception. In H.D. Kimmel, E.H. Van Olst, \& J.F. Orbeleke (Eds.). The Orienting Reflex in Humans (pp. 587605). Hillsdale, NJ: Erlbaum.

Rojo, N., \& Carrillo, J.M. (1995), La presentación de uno mismo a los demás: ¿habilidad o defensa? In M.D. Avia \& M.L. Sánchez-Bernardos (Eds.), Personalidad: aspectos cognitivos y sociales (pp. 413-425). Madrid: Pirámide.

Romero, A., Luengo, M. A., Garra, A., \& Otero-Lopez, J.M. (1994). An analysis of the dimensionality of self-monitoring. European Journal of Psychological Assessment, 10, 102-110.

Skinner, N.F., Giokas, J.A., \& Horstein, H. A. (1986). Personality correlates of Machiavellianism: 1. Consensual validation. Social Behaviour and Personality, 4, 273-276.

Snyder, M. (1974). Selt-Monitoring of expressive behavior. Joumal of personality and Social Psychology, 30, 526-537.

Snyder, M. (1987). Public appearances, private realities: The psychology of self-monitoring. New York: Freeman.

Snyder, M. \& Gangestad, S. (1986). On the nature of selfmonitoring: Matters of assessment, matters of validity. Journal of Personality and Social Psychology, 5I, 125-139.

Wertheim, E.G.. Widom, C.S., \& Wortzel, L. H. (1978). Multivariate analysis of male and female professional career choicc correlates. Joumal of Applied Psychology, 63, 234-242.

Wilson, D.S., Near, D., \& Miller, R.R. (1996). Machiavellianism: A synthesis of the evolutionary and psychological literatures. Psychological Bulletin, 119. 285-299.

Zook. A., \& Sipps, G.J. (1986). Reliability and sex differences with a gender-free Mach IV. Journal of Social Psychology, I26, 131-132.

Received June 11, 1999 Revision received December 21, 1999 Accepted January 4, 2000 